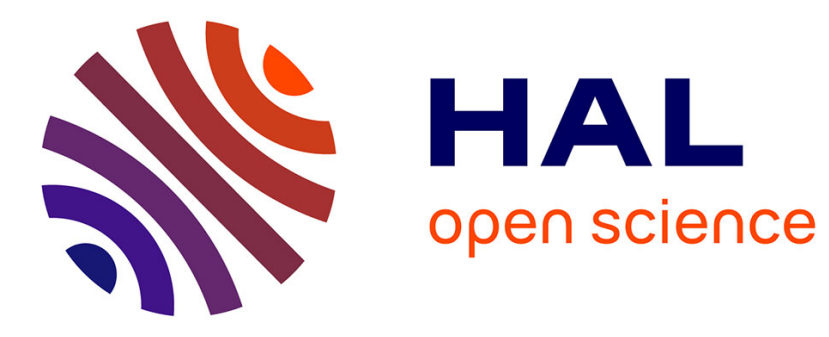

\title{
Late Paleozoic Ice Age glaciers shaped East Antarctica landscape
}

\author{
Yann Rolland, Matthias Bernet, Peter van Der Beek, Cécile Gautheron, \\ Guillaume Duclaux, Jerôme Bascou, Mélanie Balvay, Laura Héraudet, \\ Christian Sue, René-Pierre Ménot
}

\section{To cite this version:}

Yann Rolland, Matthias Bernet, Peter van Der Beek, Cécile Gautheron, Guillaume Duclaux, et al.. Late Paleozoic Ice Age glaciers shaped East Antarctica landscape. Earth and Planetary Science Letters, 2019, 506, pp.123 - 133. 10.1016/j.epsl.2018.10.044 . hal-01925658

\section{HAL Id: hal-01925658 \\ https://hal.science/hal-01925658}

Submitted on 29 Nov 2018

HAL is a multi-disciplinary open access archive for the deposit and dissemination of scientific research documents, whether they are published or not. The documents may come from teaching and research institutions in France or abroad, or from public or private research centers.
L'archive ouverte pluridisciplinaire HAL, est destinée au dépôt et à la diffusion de documents scientifiques de niveau recherche, publiés ou non, émanant des établissements d'enseignement et de recherche français ou étrangers, des laboratoires publics ou privés. 


\section{Late Paleozoic Ice Age glaciers shaped East Antarctica landscape}

Yann Rolland ${ }^{1-2}$, Matthias Bernet ${ }^{3}$, M., Peter van der Beek ${ }^{3}$, Cécile Gautheron ${ }^{4}$, Guillaume

Duclaux $^{1}$, Jérôme Bascou ${ }^{5}$, Mélanie Balvay ${ }^{3}$, Laura Héraudet ${ }^{2}$, Christian Sue $^{6}$, René-Pierre

Ménot $^{5}$

${ }^{1}$ Université Côte d'Azur, CNRS, OCA, IRD, Géoazur, 250 rue Albert Einstein, Sophia Antipolis 06560 Valbonne, France.

${ }^{2}$ EDYTEM, Université de Savoie - CNRS, UMR 5204, Le Bourget du Lac, France.

${ }^{3}$ Université Grenoble Alpes, Université Savoie Mont-Blanc, CNRS, IRD, IFSTTAR, ISTerre, 38000 Grenoble, France.

${ }^{4}$ GEOPS, Université Paris-Sud 11, CNRS, Université Paris-Saclay, Rue du Belvédère, Bât. 504, F-91405 Orsay, France.

${ }^{5}$ Université de Lyon, Université Jean Monnet and UMR-CNRS 6524, Laboratoire Magmas et Volcans, 42023 Saint-Etienne, France.

${ }^{6}$ Chrono-environnement, CNRS-UMR6249, Université de Bourgogne-Franche-Comté, 16 route de Gray, 25030

Besançon cedex, France

Citation: Rolland, Y., Bernet, M., van der Beek, P., Gautheron, C., Duclaux, G., Bascou, J., Héraudet, L., Ménot, R. P. (2019). Late Paleozoic Ice Age glaciers shaped East Antarctica landscape. Earth and Planetary Science Letters, 506, 123-133. 


\section{Abstract}

The erosion history of Antarctica is fundamental to our understanding of interlinks between climate and glacier dynamics. However, because of the vast polar ice sheet covering more than $99 \%$ of Antarctica land mass, the continental surface response to glacial erosion remains largely unknown. Over the last decade the subglacial topography of Antarctica has been imaged by airborne radar surveys. These studies revealed high and complex sub-glacial relief in the core of the East Antarctic shield, interpreted as resulting from rifting episodes and low long-term erosion rates, or repeated large-scale glacial retreats and advances. In East Antarctica, thermochronology studies have revealed a spatially localized Cenozoic erosion starting after 34 $\mathrm{Ma}$, with a maximum denudation of $2 \mathrm{~km}$ in the Lambert Trough. Low pre-glacial erosion rates before 34 Ma have been inferred since the Permian period, following a phase of significant $(>2$ $\mathrm{km}$ ) erosion during the Late Paleozoic between 350 and 250 Ma. However, the exact extent, magnitude and significance of this Late-Paleozoic erosion phase remain elusive. Here we show that homogeneous exhumation occurred at the scale of the Terre Adélie margin of East Antarctica in response to major glacial erosion during the Late Paleozoic Ice Age (LPIA). Our data require homogeneous exhumation and $>4 \mathrm{~km}$ erosion between 340 and $300 \mathrm{Ma}$, along a 600-km profile along the Terre Adélie-George V Land coast. The data are inconsistent with either exhumation during Permian rifting, or with significant $(>1.5 \mathrm{~km})$ Cenozoic glacial erosion, which requires LPIA glaciers to have been temperate, promoting glacial sliding, erosion and sediment transfer, even at high latitudes, unlike in the present situation.

\section{Introduction}

The Late-Paleozoic Ice Age (LPIA) is one of the longest and most prominent glacial events in Earth's history. It started in the Late Devonian and extended until the early Late Permian (Caputo et al., 2008; Isaacson et al., 2008, Lakin et al., 2016) and included multiple glaciations 
across Pangea, which culminated during the Late Carboniferous in the Southern Hemisphere (Isbell et al., 2012; 2016; Davydov et al., 2016). The main reasons invoked for this major icehouse phase and correlated decrease in atmospheric $\mathrm{CO}_{2}$ concentrations are (1) the expansion of land plants, which fixed organic carbon when buried in sedimentary basins (Berner, 2003; Montañez et al., 2016), and (2) tectonic enhancement of erosion due to the Hercynian orogeny (Goddéris et al., 2017). In the first case, $\mathrm{CO}_{2}$ decrease is ascribed to the activity of plants because of the accumulation and burial of organic material in broad tropical lowland basins assuming that lignin decomposers have not yet evolved (Berner, 2003), whereas in the second case, it is attributed to the fixation of $\mathrm{C}$ during weathering of silicates (e.g., Goddéris et al., 2017). How glacial erosion may have contributed to exhumation at higher latitudes in relation to the $\mathrm{CO}_{2}$ drawdown and global cooling during the LPIA, depending on the warm- or cold-based regimes of glaciers (Koppes et al., 2015), remains an unsolved issue. Antarctica was close to the South Pole during the LPIA (Isbell et al., 2012); therefore, the question of the presence of a large polar ice-sheet and of its erosive nature stands as major questions. Estimates of long-term erosion of Antarctica are variable and generally ill-defined due to the paucity of outcropping regions apart from the well-studied Trans-Antarctic mountains and the Lambert Trough, which were also influenced by post-LPIA tectonics (Arne, 1994; Lisker et al., 2003; Lisker and Olesch, 2003; Fitzgerald, 1994; Harrowfield et al., 2005) (Fig. 1). 


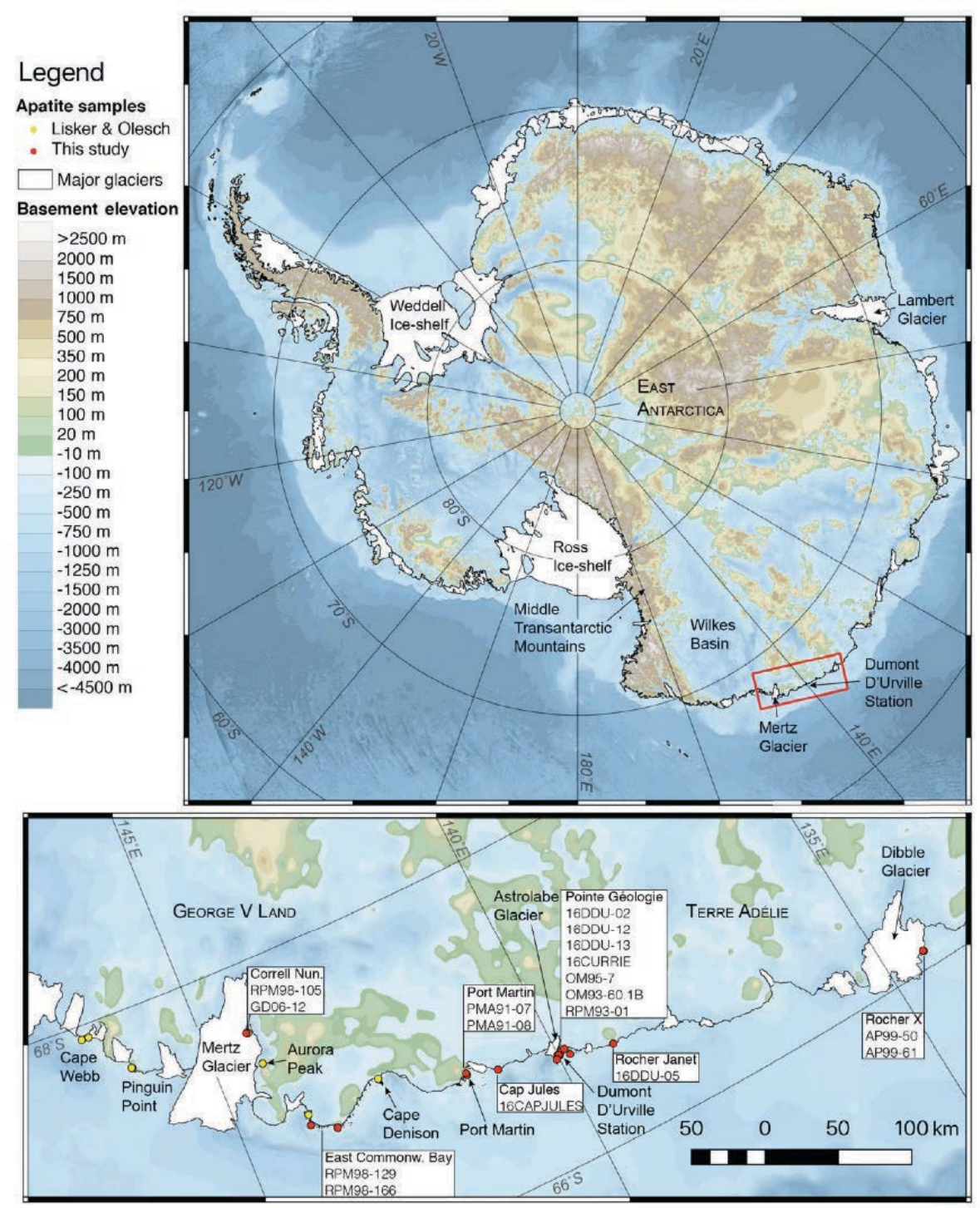

Fig. 1. Location of the investigated transect in Terre Adélie-George V Land, East Antarctica.

In this paper, the erosion history of East Antarctica is reconstructed using apatite $(\mathrm{U}-\mathrm{Th}) / \mathrm{He}$ (AHe) and fission track (AFT) thermochronology from samples collected along the coast of Terre Adélie based on apatite (U-Th)/He (AHe) and fission track (AFT) datings (Fig. 1; see Analytical Methods section 3). These results are combined with published data from George V Land (Lisker and Olesch, 2003), offering a 600-km long transect of thermochronological data from the East Antarctica Craton. 


\section{Geological Setting}

\subsection{Erosion Estimates in Antarctica}

As for all high-latitude regions, glacial erosion is presumed to be minimal due to water-free conditions and to the physical nature of a mantle of cold ice effectively protecting landscapes from erosion (e.g., Thomson et al., 2010). Koppes et al. (2015) found that glacier erosion rates decrease by three orders of magnitude from Patagonia to the Antarctica Peninsula, across $19^{\circ}$ of latitude. These results imply that the glacier thermal regime evolves as a function of climate, and controls erosion rates more than do ice cover volume, ice flux or glacier sliding speed (Koppes et al., 2015). In the most incised East Antarctica subglacial topography (Lambert Glacier at $70^{\circ} \mathrm{E}$ ), Cox et al. (2010) and Thomson et al. (2013) documented a no erosion during the Mesozoic erosion and very low Cenozoic erosion commencing at $34 \mathrm{Ma}$, with some localized maxima of $\sim 2 \mathrm{~km}$. However, in this region of East Antarctica most of the bedrock AFT thermochronological data preserves $>100 \mathrm{Ma}$ apparent cooling ages, with a majority of ages $>250 \mathrm{Ma}$, which reflects slow cooling through the apatite fission-track partial annealing zone and thus inefficient Mesozoic to Cenozoic erosion at a regional scale with long-term average erosion rates of $0.01-0.02$ $\mathrm{km} / \mathrm{Myr}$ for at least $250 \mathrm{Ma}$ (Cox et al., 2010). In contrast, on the basis of aerogeophysical data, in the Sabrina Subglacial Basin region of East Antarctic at $110-120^{\circ}$ E, Aitken et al. (2016) propose that efficient erosion has shaped the subglacial basement by repeated largescale glacier retreat and advance. These authors suggest that such intense phases of Cenozoic erosion explain the reduction or absence of sedimentary basins in this region. Just east of this area, the Terre Adélie forms a 'highland' below the ice cap between 125 and $146^{\circ} \mathrm{E}$, and is devoid of any sedimentary basin (Aitken et al., 2016; Fig. 1). It is thus a perfect place to test the hypothesis of significant Cenozoic ice cap erosion. 


\subsection{Terre Adélie and George V Land}

In the Terre Adélie and George V Land region, exposures occur mainly along the coast, on small $<1 \mathrm{~km}^{2}$ islands. The Terre Adélie crystalline basement is made of high-grade metamorphic rocks (granulites) dating from the Neoarchean (c. $2.5 \mathrm{Ga}$ ) and the Paleoproterozoic (1.6-1.7 Ga; e.g., Ménot et al., 2005; 2007). The last major tectonic event affecting this region corresponds to the Ediacaran accretion (c. $515 \mathrm{Ma}$ ) of a tectonic block on the Eastern margin of the Terre Adélie craton in eastern George V Land (Lamarque et al., 2018). This event had no thermal impact in the core of the craton (Duclaux et al., 2008). No sedimentary basins are exposed within the craton, the most superficial rocks being metamorphic rocks in the Upper Greenschist facies (Cape Hunter phyllites, P 4-5 kbar and $\mathrm{T} \sim 300-400^{\circ} \mathrm{C}$; e.g., Duclaux et al., 2008). Very little post-Proterozoic deformation has been recognized in the geological basement of Terre Adélie. Rare signs of brittle deformation are discrete E-W faults and joints ascribed to rifting of the Antarctic Ocean during the Mesozoic (160-95 Ma). Before this study, no thermochronological data were obtained in Terre Adélie. To the East, in the George V Land, close to the Mertz glacier area (Fig. 1), AFT ages are spread between 283 and $236 \mathrm{Ma}$ (Lisker and Olesch, 2003). Similar AFT ages, ranging from 350 to $250 \mathrm{Ma}$ were obtained in the Miller Range of the Tansantarctic mountains (Fitzgerald, 1994), in the Lambert Glacier area $\left(70^{\circ} \mathrm{E}\right.$, Arne, 1994; Lisker et al., 2003), and in SE Australia (e.g., Foster and Gleadow, 1992). Therefore, a Late Paleozoic exhumation phase is suggested from this large 350-250 Ma AFT domain, although its meaning (erosion or unroofing in response to arc/ back-arc tectonics, rifting, or due to efficient climate-related processes) is still a matter of debate. Several studies interpreted the Late Paleozoic thermochronological ages and cooling episodes as resulting from rifting processes (e.g., Arne, 1993). In the George V Land, Lisker and Olesch (2003) interpret their dataset in terms of a gradual long-term (Carboniferous to Triassic) denudation in the order of 3-4 km, 
correlating with coeval crustal extension and the formation of the Wilkes Basin, which would have opened as a back-arc or retro-arc basin. But this extension and any other formal evidence of tectonic activity along potential N-S extensional faults in this time range in Antarctica is based on the interpretation of geophysical data of sub-glacial domains (e.g., Harrowfield et al., 2005; Ferraccioli et al., 2011). In addition, given the absence of any detailed modelling of the cooling history based on fission track lengths it remains difficult to relate these cooling ages to a proper Late Paleozoic major rift-driven exhumation phase. The only rifting phase, which is clearly evidenced in this region of Pangea is documented East of Adelaide, where interruption of the $>250$ Ma AFT ages by a domain of Mesozoic AFT ages is ascribed to the E-W rifting phase, which commenced at $160 \mathrm{Ma}$, and later led to ocean opening and Australia-Antarctica drift since $95 \mathrm{Ma}$ (Foster and Gleadow, 1992).

\section{Analytical Methods}

Low-temperature thermochronology is applied to pinpoint the cooling and exhumation history of upper crustal rocks (e.g., Reiners and Brandon, 2006). This method makes it possible to accurately recalculate the T-t (Temperature-time) cooling path of individual samples, and allows to reveal rapid or slow exhumation events, even in cases of long a long stagnation of rocks at intermediate $(2-6 \mathrm{~km})$ depths. We used apatite $(\mathrm{U}-\mathrm{Th}) / \mathrm{He}(\mathrm{AHe})$ and apatite fissiontrack (AFT) thermochronology, sensitive to closure temperatures ranging from $\sim 50$ to $\sim 110^{\circ} \mathrm{C}$ for cooling rates of about $10{ }^{\circ} \mathrm{C} / \mathrm{Myr}$ (e.g. Gallagher et al., 1998; Flowers et al., 2009). The combination of these two thermochronometers provides information on the cooling trajectories of rocks and can be used to estimate rates of erosional and tectonic exhumation at levels close to the surface.

Fission tracks are linear damage zones in the mineral lattice produced by the spontaneous fission of ${ }^{238} \mathrm{U}$, which accumulate and are preserved through time when the host mineral cools 
below the closure temperature, which is $\sim 60-120^{\circ} \mathrm{C}$ for apatite (Gallagher et al., 1998). This temperature interval is defined as the Apatite Partial Annealing Zone or APAZ. The (U-Th)/He thermochronometer is based on the in-growth of ${ }^{4} \mathrm{He}$ produced by the decay of $\mathrm{U}$, Th and $\mathrm{Sm}$, and on its retentivity in its host mineral. In apatite, helium is wholly retained below $\sim 40^{\circ} \mathrm{C}$ and rapidly diffuses out of the crystal above $\sim 120^{\circ} \mathrm{C}$ with the intervening temperature interval defining the partial retention zone (APRZ; e.g., Wolf et al., 1998). The closure temperature depends on the cooling rate, grain size, radiation damage that depend on the time and effective uranium content (Ehlers et al., 2005), which given damage content returns an APRZ temperature range (Flowers et al., 2009; Gautheron et al., 2009) that can be similar or even higher temperature than the APAZ in the dated samples. In addition, during alpha decay, a 10 to $30 \%$ of the produced $\mathrm{He}$ is lost by ejection outside of the crystal and a correction is applied to the AHe age (Farley et al., 1996). In the case of U zoned apatite as observed by fission track density (Fig. 2), the ejection correction can be less or more important (Gautheron et al., 2012).

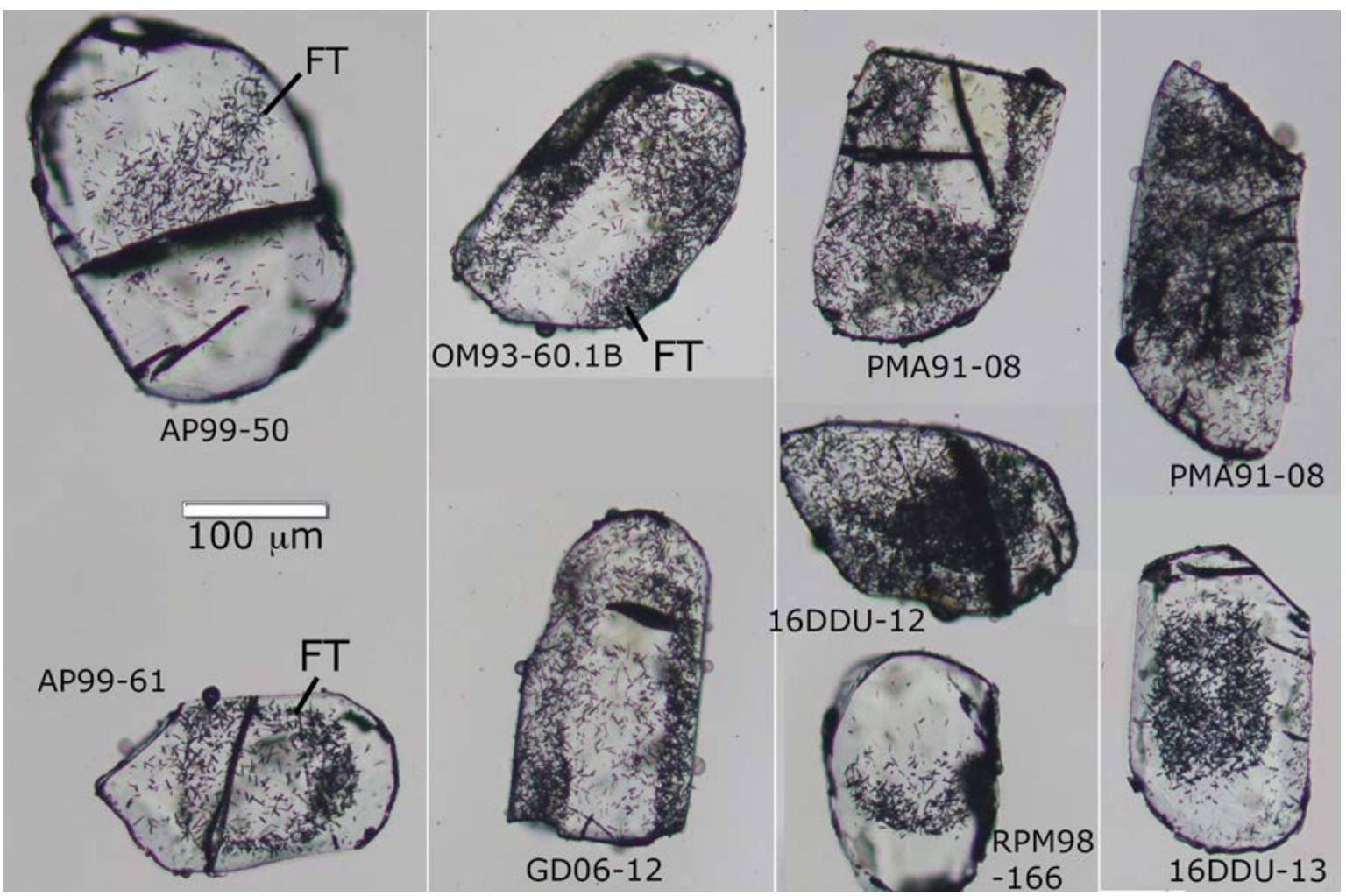


Fig. 2. Photographs of dated apatite grains from Terre Adélie with a zoned distribution of fission tracks (FT), related to mineral U zoning.

In case of monotonic cooling, the closure temperature can be converted into a depth estimate after estimating the paleogeothermal gradient; the obtained cooling rate can then be translated into an exhumation rate. However, a long episode of slow cooling and/or a long hold time within the APAZ, will lead to shortening of tracks at temperatures as low as $60^{\circ} \mathrm{C}$ (Reiners and Brandon, 2006), and thus to a younging of the apparent cooling age. In this case, the age has no geological meaning, but the sample T-t history can be modelled based on the track-length distribution. The T-t cooling path can be used to infer the corresponding main exhumation phases and the potential phases of tectonic stagnation.

We measured Terre Adélie sample AFT ages of collected Terre Adélie samples at the ISTerre (Univ. Grenoble Alpes, France) fission-track laboratory and AHe ages at the GEOPS (Univ. Paris Sud, France) low temperature laboratory, respectively. Modelling of the Temperaturetime history was undertaken using the HeFTy software (Ketcham et al., 2007) based on the AFT data.

\section{Results}

\subsection{AFT and AHe Results}

The AFT and AHe results (Fig. 3; Tables 1-2) are combined with published AFT data in the adjacent Georges V Land (Lisker and Olesch, 2003), which provides a 600-km transect of East Antarctica basement, including an overlapping sampling zone allowing direct comparison of the datasets (Fig. 4). 


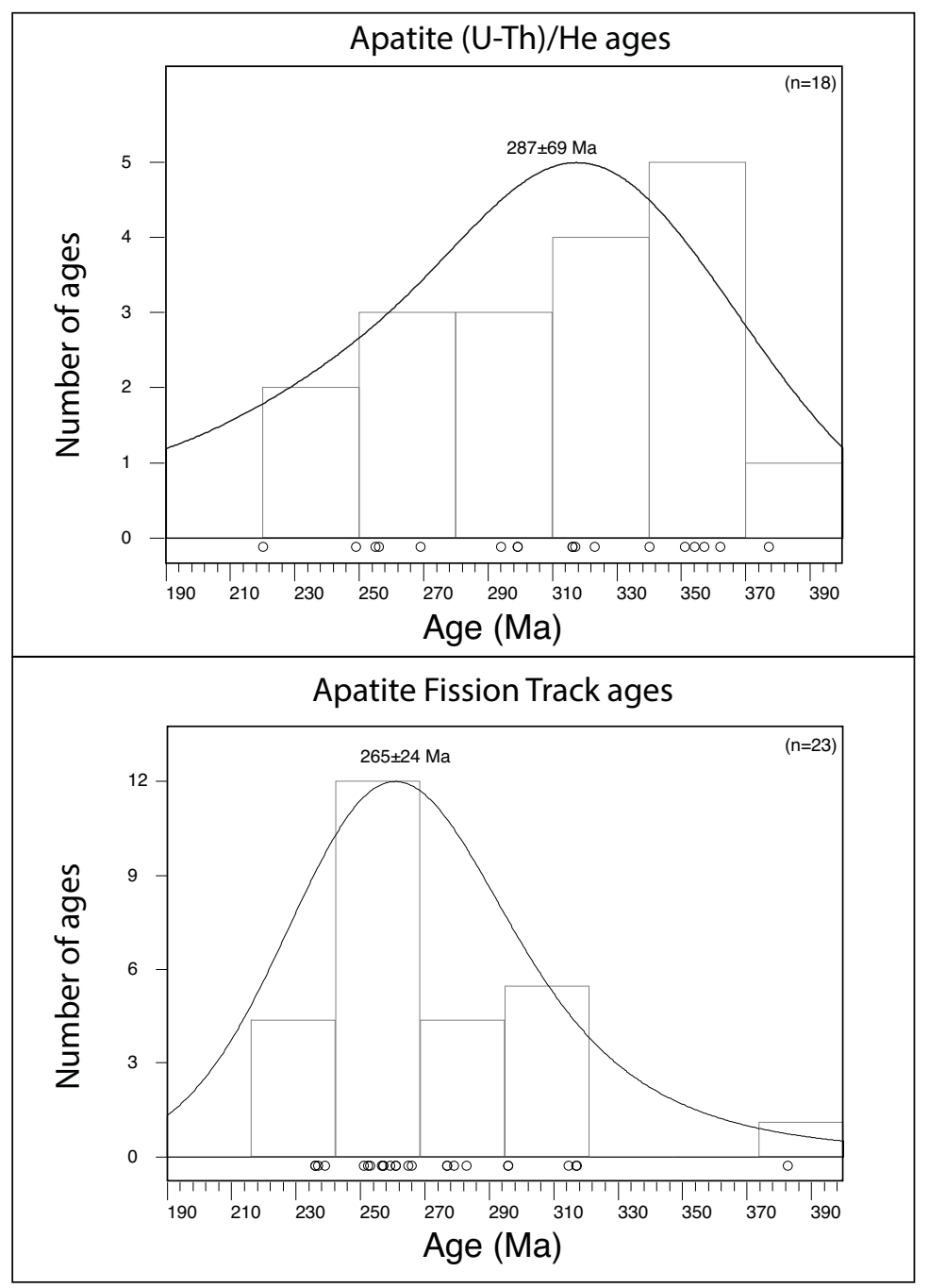

Fig. 3. Central AFT and individual alpha ejection corrected AHe results and age probability curves. 


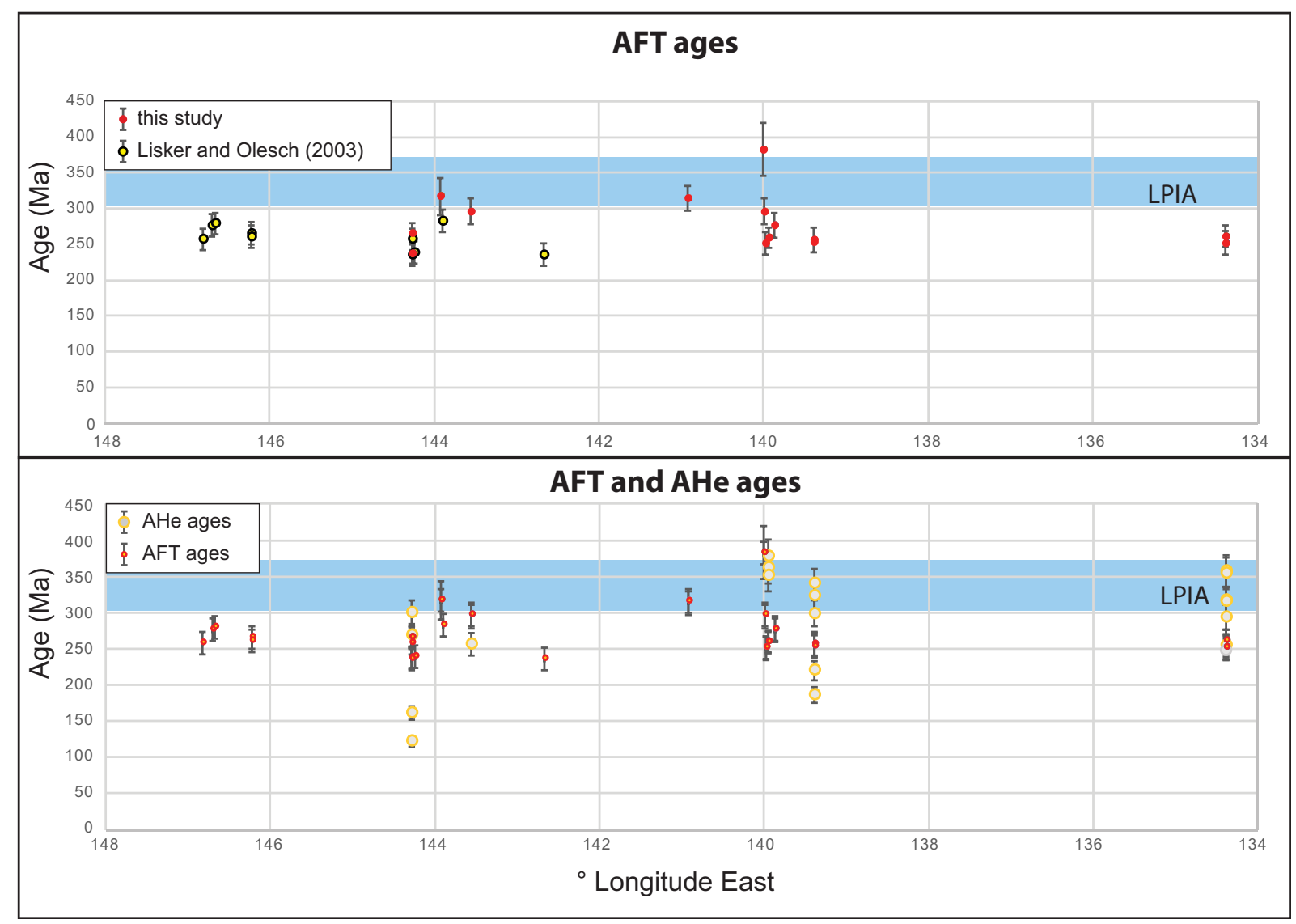

Fig. 4. Central AFT and individual alpha ejection corrected AHe results plotted on a transect along the Terre Adélie - George V coast.

AFT ages are all within the range 380-240 Ma at the scale of the Terre Adélie - George V coast (Fig. 4). However, if the temperature remained within the Apatite Partial Annealing for a long time, this age span can only be reliably attributed to an exhumation age after taking into account the fission track lengths (see section 3). When retained in the APAZ, a significant length of the fission tracks was annealed, and thus the AFT age has no geological meaning but it remains possible to accurately recalculate the T-t cooling path of the samples based the c-axis projected mean track lengths (e.g., Gallagher et al., 1998).

As implied by the c-axis projected mean track lengths of our samples (13.2-14.4 $\mu \mathrm{m})$, the Permian central AFT ages (265 $\pm 24 \mathrm{Ma}, 2 \sigma$; Fig. 2) reflect partial annealing of fission-tracks in apatite during a long episode of slow cooling. Shortening of tracks occurred at temperatures 
as low as $60{ }^{\circ} \mathrm{C}$, especially for F-apatites (small Dpar values of $<1.75 \mu \mathrm{m}$; Ketcham et al., 2007). This results in central fission-track ages that are younger than the time when cooling started (see examples and details in Gallagher et al., 1998). The mean raw AHe age is of $227 \pm 57$ Ma and is corrected due to alpha-ejection using the FT factor calculated using a homogeneous U-Th repartition into the apatite crystal (Farley et al., 1996; Ketcham et al., 2011). Resulting AHe alpha ejection corrected age is of $287 \pm 69 \mathrm{Ma}$, which is similar to the AFT ages (Fig. 2). The AHe data shows a grain age dispersion for each sample in function of uranium effective $\mathrm{eU}$ content ( $\mathrm{eU}=\mathrm{U}+0.24 \mathrm{Th})$, apart from one replicate, as illustrated in Fig. 5.

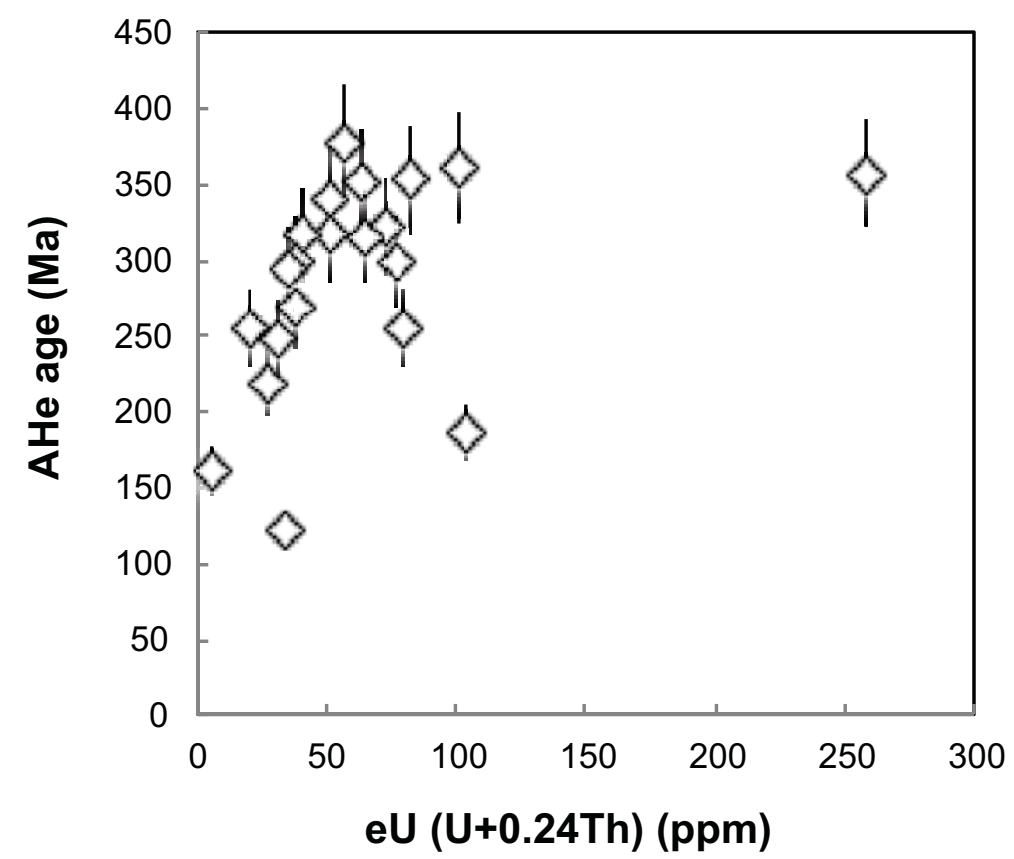

Fig. 5. Corrected AHe age versus effective uranium eU concentration.

The AHe age dispersion thus indicates a long stay in the APRZ and is correlated to the amount of damage caused by natural radioactivity (Shuster et al., 2006; Gautheron et al., 2009). The $\mathrm{eU}$ value is a proxy for damage content and so He retentivity is proportional to eU concentration. However, U zoning observed in the AFT samples (Fig. 2) indicates that the alpha ejection factor is certainly overestimated by a factor of $10-15 \%$ resulting in younger corrected AHe ages (Gautheron et al., 2012). Based on these data, the AHe ages are considered as 
minimum ages like the AFT ages. Both the AFT and AHe data indicate that the rocks rapidly cooled during the LPIA and remained a long time in the APAZ since the Early Permian.

AHe ages $(287 \pm 69 \mathrm{Ma}, 2 \sigma)$ are more spread out than AFT ages (265 $\pm 24 \mathrm{Ma}, 2 \sigma)$, which is ascribed to He retention due to $\mathrm{U}$ zoning of grains and low diffusivity in these strongly $\alpha$ damaged apatites (Hourigan et al., 2005; Gautheron et al., 2012; see methods and Fig. 2).

\section{2. $t$-T modelling}



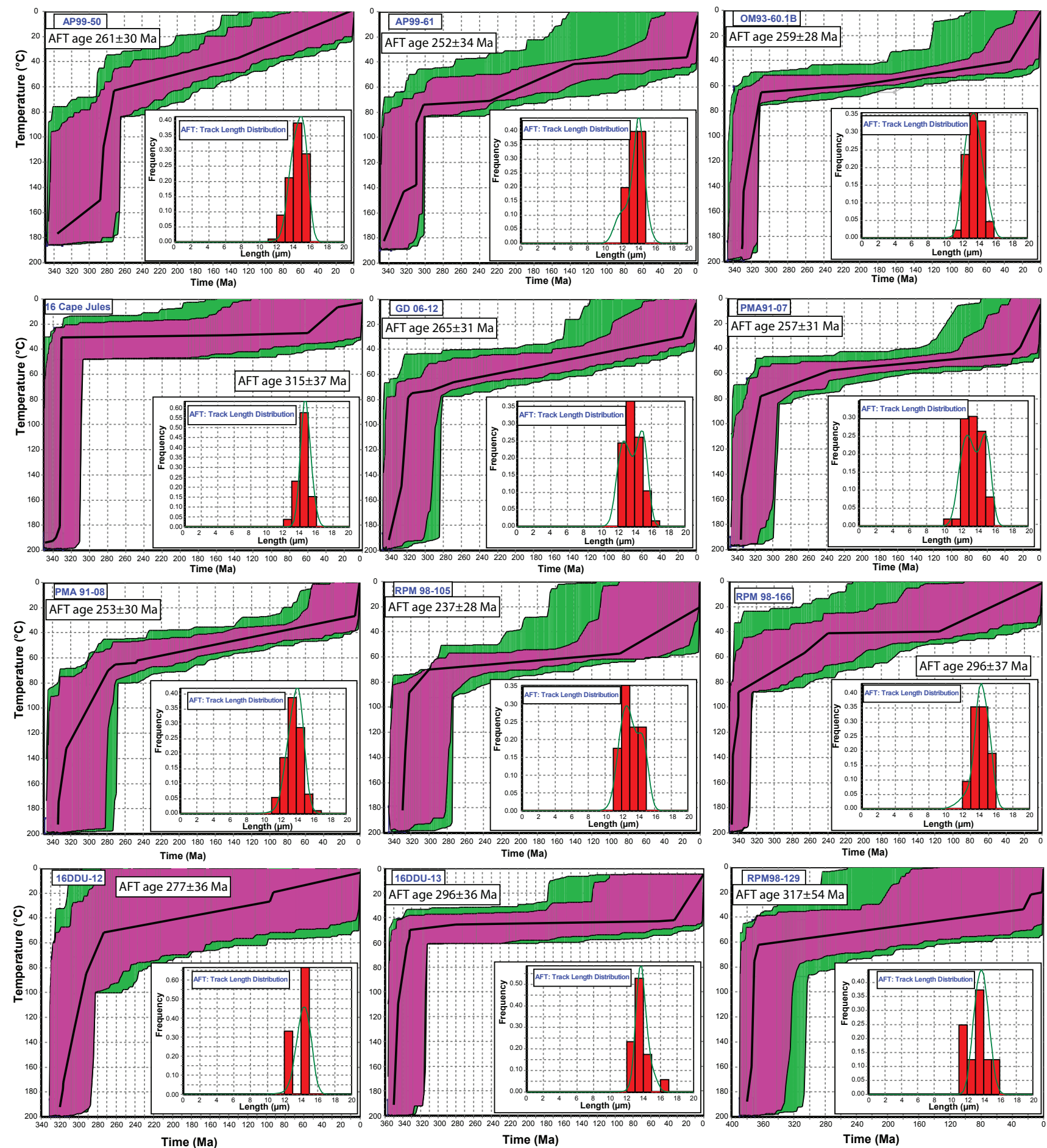

Fig. 6. AFT time-temperature results using HeFTy modelling (see parameters in Table 3).

Terre Adélie is a stable craton with a present-day crustal thickness of 40-45 km (Lamarque et al., 2015); we therefore assume a temporally constant upper-crustal geotherm ranging from 20 to $30{ }^{\circ} \mathrm{C} \cdot \mathrm{km}^{-1}$, implying that the AHe and AFT data record exhumation from $\sim 3$ to $\sim 5 \mathrm{~km}$ depth, 
respectively. On the basis of AFT data, our t-T modelling (Fig. 6) and a temperature-to-depth conversion using a geothermal gradient of $25^{\circ} \mathrm{C} \mathrm{km}^{-1}$ concur to a major phase of exhumation between 340 and 300 Ma time-integrated exhumation rates of $0.15 \mathrm{~mm} \mathrm{yr}^{-1}$ for the $340-300 \mathrm{Ma}$ time range, with an abrupt decrease at ca. 300-280 Ma, followed by slow exhumation $<0.005$ $\mathrm{mm} \mathrm{yr}^{-1}$ until $30 \mathrm{Ma}$ (Fig. 7). No significant lateral variation in cooling age history is evidenced along the $600-\mathrm{km}$ studied section. Since $30 \mathrm{Ma}$, a slight increase in exhumation rates is likely, representing less than $1.5 \mathrm{~km}$ of exhumation.

\section{Discussion}

\subsection{Significance of LPIA exhumation history}

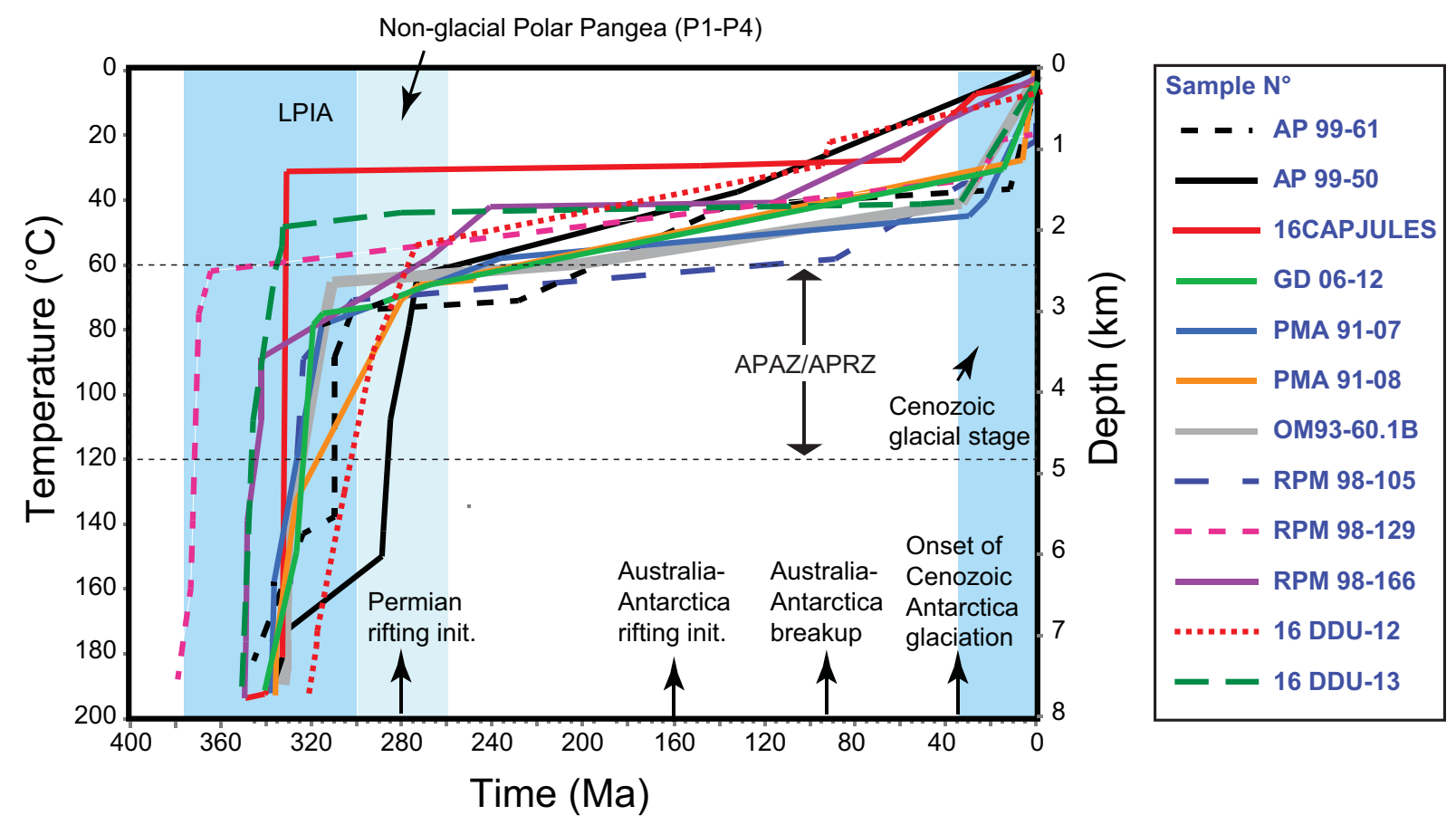

Fig. 7. Summary of time-temperature results using HeFTy modelling, with main tectonic events and glaciations of the Phanerozoic (Isbell et al., 2012; Veevers, 2006). APAZ: Apatite Partial Annealing Zone of Fission Tracks and APRZ: Apatite Partial Retention Zone of He (see Analytical methods section 3). LPIA: Late-Paleozoic Ice Age. P1-P4: glaciation events occurring in Australia in the Permian (300-260 Ma). The depth, in kilometres, or equivalent amount of exhumation is estimated based on a thermal gradient of $25^{\circ} \mathrm{C} \cdot \mathrm{km}^{-1}$. 
Similar 340-300 Ma thermochronological ages were obtained in the Miller Range of the Middle Transantarctic Mountains (Fitzgerald, 1994) and around the Lambert Trough towards western East Antarctica (Arne, 1994; Lisker et al., 2003). Combined, these data suggest a major cooling event occurred during the LPIA, which largely affected East Antarctica s.l. and had a minor effect in Southeast Australia. The large-scale homogeneity of LPIA exhumation and the absence of conspicuous spatial relationships with extensional faults are inconsistent with previous rifting models proposed for East Antarctica during the Late Paleozoic, although rifting clearly occurred later in the Mesozoic and Cenozoic (Lisker et al., 2003; Harrowfield et al., 2005). Therefore another, non-tectonic, cause is likely. This cooling phase coincides with low $\mathrm{pCO}_{2}$ values $(<2000 \mathrm{ppmv}$ ) estimated during the LPIA from 340 to $300 \mathrm{Ma}$ (Montañez and Poulsen, 2013; Montañez et al., 2016; Chen et al., 2018)(Fig. 8). A sea-level fall starting at 340 Ma, with a peak of $\sim-30$ to -70 meters (Rygel et al., 2008; Campion et al., 2018) at 310-290 Ma supports the development of some extensive polar ice sheets in this time range. Hence, exhumation in East Antarctica was coeval with glacial erosion during the LPIA.

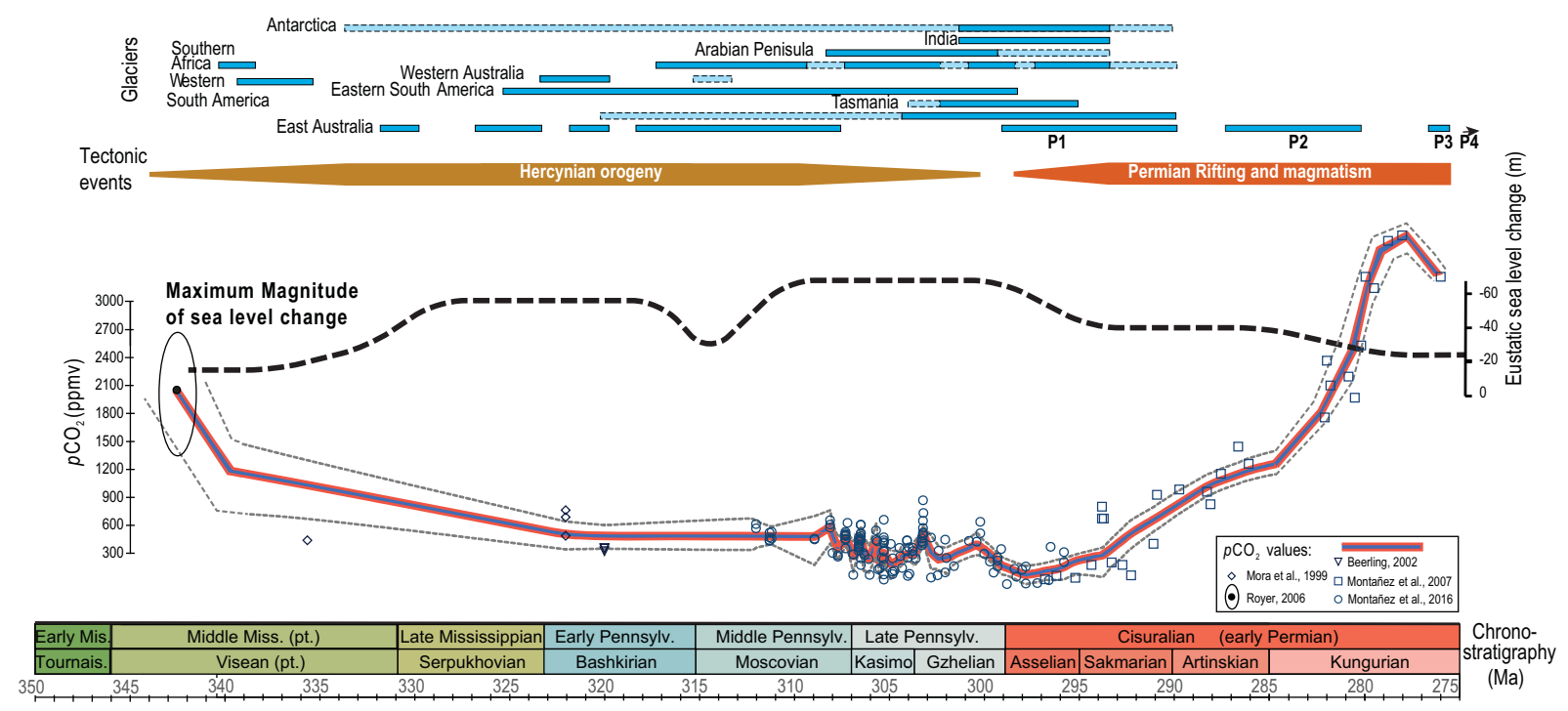

Fig. 8. Glaciations, tectonic events, sea-level change and $\mathrm{pCO}_{2}$ variations versus time during the LPIA and following glacial and non-glacial intervals in the Permian. Reconstructions of glaciations are after Montañez and Poulsen (2013) and Isbell et al. 
(2012); $\mathrm{pCO}_{2}$ data are from Montañez et al. (2016); Chen et al. (2018), and references therein. Maximum Magnitude of sea level change is from Rygel et al. (2008) and Campion et al. (2018).

\subsection{Extension of LPIA Antarctic ice sheet(s)}

Based on the locations reported for Late Carboniferous-Early Permian AFT cooling ages across East Antarctica, on the position of periglacial basins, and on the directions of glacier transport compiled in Isbell et al. (2012), we propose that a large ice cap has covered the East Antarctica during the LPIA (Fig. 9), with a minimum dimension $>2 \times 10^{6} \mathrm{~km}^{2}$, which corresponds approximately to the Terre Adélie-Georges V land craton (Fig. 9) or to the Victoria Land ice spreading center defined by Isbell (2010). This large glacier coincided with the Late Carboniferous (330-300 Ma) South Paleopole (Fig. 9). Fieldworks along the Transantarctic Mountains highlight tillite formations featuring glacio-marine conditions, overlying a weathered basement suggesting limited glacial denundation during the LPIA (e.g., Dow and Neall, 1974, Koch and Isbell, 2013). Koch and Isbell (2013) suggest that the tillites were deposited at the front of a tidewater glacier terminus, which would originiate from the core of East Antarctica, in agreement with a glacial center positioned on the Terre Adélie - Georges V craton. Given the homogeneity of T-t profiles and apatite thermochronological ages along the Terre Adélie - George V Land coast (Fig. 7), along a 600-km transect, it is likely that erosion was driven by a single ice sheet at the scale of the craton, which could have been slightly higher due to its crustal thickness $>45 \mathrm{~km}$ in the Late Paleozoic (Lamarque et al., 2015). Although data is still lacking in Antarctica to infer the extent of ice sheets, ice flow patterns are in agreement with several glacial centres in Antarctica during the LPIA. 


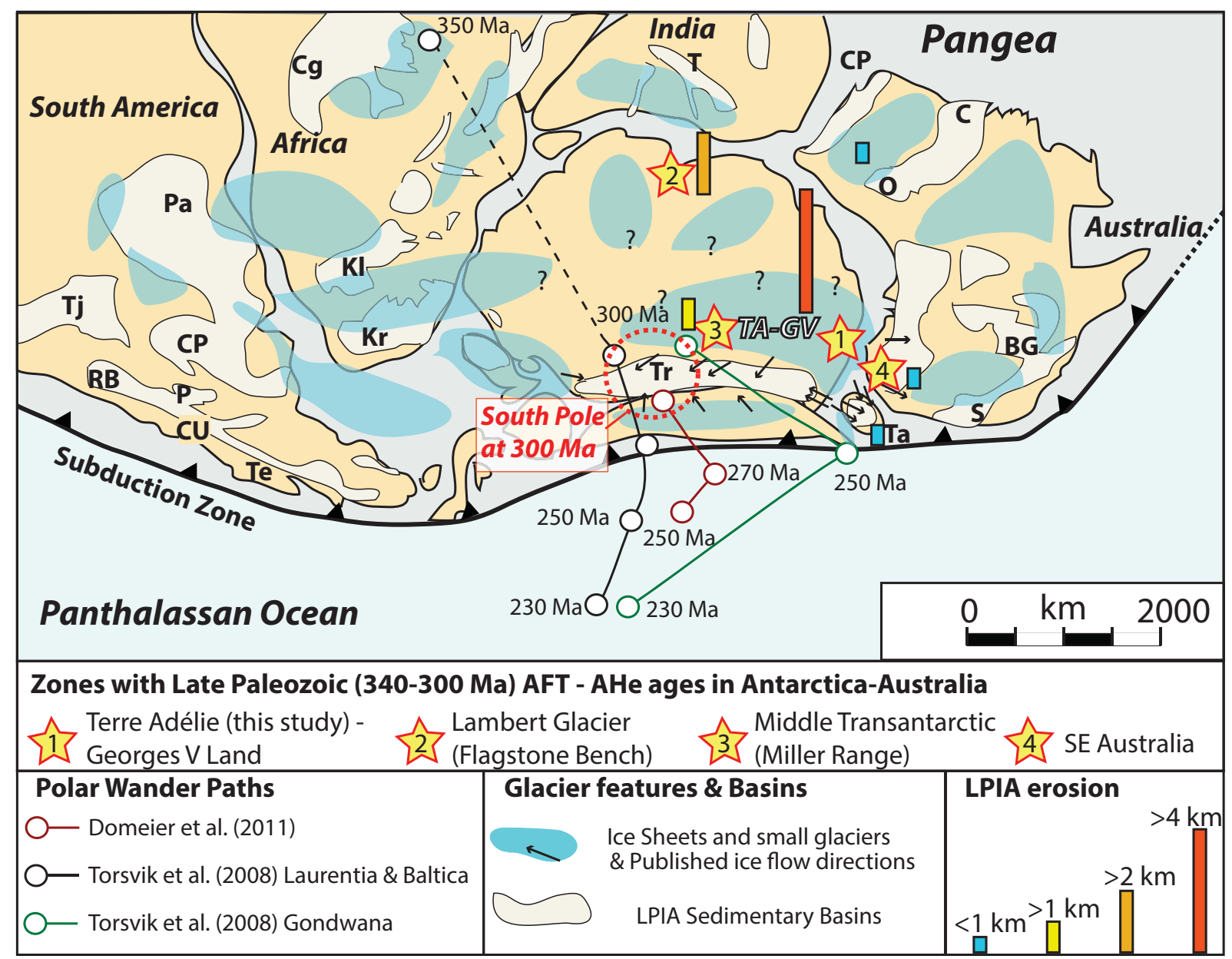

Fig. 9. Reconstruction of Maximum glaciation during the LPIA (at c. $300 \mathrm{Ma}$ ) based on data glacier data compiled in Isbell et al. (2012). Positions of several LPIA Antarctic ice sheets is suggested following ice flow directions. The Terre-Adélie-Georges V glacier (TA$\mathrm{GV}$ ) is proposed as one of the main Antarctic glaciers based on combined erosion along Terre Adélie coast and constant ice flow directions along the Tans-Antarctic mountains, while others remain speculative. Main LPIA Basins: B-G: Bowen-Gunnedah; C: Canning; Co: Congo; CP: Carnarvon/Perth; CU: Calingasta-Upsalla; Kl: Kalahari; Kr: Karoo; O: Officer; P: Paganzo; Pa: Paranà; RB: Rio Blanco; S: Sydney; T: Talchir; Ta: Tasmanian; Te: Tepuel; Tj: Tarija; Tr: Transantarctic. Position of the South Paleopole at $300 \mathrm{Ma}$ is constrained from Torsvik et al. (2008) and Domeier et al. (2011), and the proposed Polar wander paths are shown from 350 to $230 \mathrm{Ma}$.

Fieldworks and combined topographic analysis of the Antarctic shield suggest that up to five small temperate ice sheets occurred in South Polar Antarctica during the late Paleozoic ice age rather than a single massive ice sheet (Koch and Isbell, 2013). Still, the too scattered 
thermochronological data do not allow to correlate them as being representative of a unique upland (Fig. 9). Paleocurrent patterns might suggest an Antarctic Highland centred in the Gamburtsev Subglacial Mountains (Veevers, 2006). However, a detailed look at flow patterns does not support such an interpretation, as it is shown to be quite complex (e.g., Frakes et al., 1971; Hand, 1993; Isbell, 2010, Isbell et al., 2008). The Antarctic subglacial topography is also very complex, and is either ascribed to the Cenozoic advance of glaciers (e.g., Aitken et al., 2016) or to some inherited relief from the Mesozoic or Paleozoic (e.g., Ferraccioli et al., 2011). Thermochronological data from this article suggest a very low Cenozoic erosion, which is in agreement with the inheritance of topography from the late Paleozoic. It follows that the hypothesis of a single large Antarctic Highland (Veevers, 2006) is not valid, and we suggest that several ice centers occurred in Antarctica in the Paleozoic.

\subsection{Style of glacial erosion in the Antarctic during the Cenozoic and LPIA}

A striking result emerging from this thermochronological study concerns the style of glacial erosion in the Antarctic polar region during the LPIA, as deduced from the above erosion estimates ( $>4 \mathrm{~km}$ erosion between 340 and $300 \mathrm{Ma}$ ). This study is in agreement with previous ones from around Antarctica showing a very limited amount of focused Cenozoic glacial erosion, in any case less than 1.5-2 km (Ferraccioli et al., 2011; Aitken et al., 2016). Limited Cenozoic erosion is ascribed to cold-based glaciers at high latitudes, in contrast to the temperate glaciers occurring at lower latitudes (Koppes et al., 2015). In cold-based glaciers, no water flows at the base and movement occurs in the glacier mass only, preventing the development of basal sliding and friction (Cuffy and Paterson, 2010). It is therefore likely that climatic conditions during the LPIA precluded the polar glaciers or ice caps to behaving in a cold-base mode like in the Cenozoic. Several mechanisms account for such a more temperate climate in the polar region during the LPIA, like: (i) the absence of any peri-Antarctic atmospheric 
circulation due to the continental climate that dominated the interiors of the wide Pangea supercontinent, (ii) a more dynamic ice cover, with numerous glacial and interglacial phases, which might have been promoted by a relatively high equilibrium-line altitude (Isbell et al., 2012). However, such processes remain to be tested in future work.

\subsection{Presence or absence of tectonic-driven uplift}

The erosion estimates derived from thermochronology in the Terre Adélie craton during the LPIA (section 4.2, Fig. 7) imply a rate of about $0.1 \mathrm{~mm}^{\mathrm{yr}}{ }^{-1}$. In comparison, various estimates for the Laurentide Ice Sheet using estimates of derived sediment over the last 3 Ma have a range of 6 to 120 m cumulative denudation (e.g., Bell and Laine, 1985; Hay et al., 1989). Higher erosion rates for Alaskan Glaciers of $0.2 \mathrm{~mm} \mathrm{yr}^{-1}$ have been reported (e.g., Hallet et al., 1996), however, these involve uplift associated with active margin tectonism. In the St. Elias Mountains, rapid denudation of $\sim 5-10 \mathrm{~km}$ has been identified by glacial erosion in a highly active margin (Enkelmann et al., 2010). Therefore, despite the fact that a different (hot-based) and dynamic ice erosion is requested for such a sustained erosion during the LPIA, it seems necessary to invoke some tectonic uplift. The major LPIA Terre Adélie - Georges V glacier in Fig. 9 runs along the transantarctic mountains. This orientation is thus parallel to the active margin along Australia to Patagonia during the LPIA. Therefore, it is likely that uplift was also driven by subduction-driven mantle flow below the overriding plate. However, at present, no geological evidence (magmatic dykes or tectonic structures) of LPIA age of such asthenospheric flow is found in the field in the Terre Adélie domain, so the contribution of tectonics to the uplift remains highly speculative.

\subsection{A transition towards an ice-free south pole in the Early Permian}


Our dataset is in agreement with an abrupt ending of the LPIA at c. 300-280 Ma. The question for the abrupt climate change at the ending of the LPIA, leading to waning of the polar Antarctica ice cap is posed. In the geological record, sharp contacts clearly separate glacigenic deposits from post-glacial strata in the Middle Sakmarian ( 290 Ma; Isbell et al., 2012). Our results are thus in agreement with conditions evolving from a glacial to a non-glacial Polar Pangea at this major climatic transition. This drastic drop of the Antarctic erosion rates is ascribed to an 'icehouse to greenhouse transition' at the end of the LPIA (e.g., Isbell et al., 2012), although the origin of this transition is still unclear. Several hypotheses can be proposed: (i) in the Permian, the assembly of Pangaea promoted arid conditions in continental interiors, which led to a deficit of precipitation into the glacier budget, (ii) due to extensional tectonic collapse of the Hercynian chain after $300 \mathrm{Ma}$, the lowering of the mountains led to a reestablishment of thick soils, which combined to the arid conditions was unfavorable for silicate weathering (Goddéris et al., 2017). These changes allowed $\mathrm{CO}_{2}$ concentrations to rise to levels sufficient to terminate the glacial event (Fig. 8). (iii) Further, the South Pole was not positioned on the continent after $270 \mathrm{Ma}$ (Fig. 9), which changed the atmospheric circulation pattern and led to the warming of Pangea. This factor must be put in relation with the equilibrium-line altitude or ELA (e.g., Ohmura et al., 1992). In the ELA, paleotopography and paleolatitudes are both acting as a built-in 'drivers' for glaciation, in other words in function of latitude, elevations must be above the ELA for glaciers to form. Due to the collapse of the Hercynian chain, the rise in $\mathrm{pCO}_{2}$ rapidly pushed the ELA up, and given the low altitude hypothesized for Antarctica in the Late Paleozoic after the major LPIA glaciation, the conditions for a significant glaciation vanished rapidly after $300 \mathrm{Ma}$. Our inference that the LPIA Antarctic sheet was warm-based is supports for hypotheses that it was slightly above the ELA. Hence, the positive feedback between Antarctica deglaciation and the Hercynian chain collapse on the increase of $\mathrm{pCO}_{2}$ might have accelerated the climate change at c. 300 Ma. However, several more minor 
glacial events still occurred in the Permian, mainly in neighbouring Australia. The extent of ice decreased through the main three glaciations documented in the Permian times until $260 \mathrm{Ma}$ (e.g., Veevers, 2006; Isbell et al., 2010; 2012), and the glaciers were gradually circumscribed to SE Australia, as Pangea drifted towards lower latitudes.

\section{Conclusion}

Most unexpectedly, the thermochronological data obtained on the Terre Adélie region of East Antarctica do not show evidence for any significant Cenozoic glacial erosion. Cenozoic denudation is very low in the studied region and resulted in less than $1.5 \mathrm{~km}$ erosion even in the influence zone of large glaciers such as the Mertz Glacier. In contrast, our data exhibits an exhumation record attributable to the major Late Paleozoic glacial event, the LPIA. This glaciation event was centered close to the current south pole and lasted for $\sim 40 \mathrm{Ma}(340-300$ Ma). This major glaciation centered in the Terre Adélie - Georges V craton resulted in the denudation of a $>4-\mathrm{km}$ thick crustal section in this region, which explains the absence of any Paleozoic sedimentary basin in this domain. This result is in agreement with LPIA glacier dynamics being driven by temperate glaciers, which promoted glacial sliding, erosion and sediment transfer, even at high latitudes, unlike in the present situation. The ending of the LPIA was very abrupt at 300-280 Ma, as shown by a clear deflection in the T-t path of all the thermochoronological record. The cessation of erosion is ascribed to a rapid warming event and occurrence of a non-glacial polar Pangea, probably due to a shift of the pole out of mainland Pangea.

\section{Acknowledgements}

This work was supported by a LABEX grant of University Grenoble Alpes and ISTerre, and received additional funding from 'UFC Besançon / UMR Chrono- 
Environnement' and Geoazur. The IPEV supported numerous field seasons in Terre Adélie, through the GEOLETA and ARLITA programmes. We acknowledge the help of F. Coeur and F. Senebier in the mineral separation process and Rosella Pinna-Jamme for her help during (UTh)/He analysis. Editorial handling of An Yin and in-depth anonymous reviewer comments have helped to significantly improve the first version of this article.

\section{References}

Aitken, A. R. A., Roberts, J. L., Van Ommen, T. D., Young, D. A., Golledge, N. R., Greenbaum, J. S., et al., 2016. Repeated large-scale retreat and advance of Totten Glacier indicated by inland bed erosion. Nature 533(7603), 385 .

Arne, D. C., 1994. Phanerozoic exhumation history of Northern Prince-Charles-Mountains (East Antarctica). Antarct. Sci. 6, 69-84.

Bell, M., Laine, E. P., 1985. Erosion of the Laurentide region of North America by glacial and glaciofluvial processes. Quaternary Research 23(2), 154-174.

Berner, R. A., 2003. The long-term carbon cycle, fossil fuels and atmospheric composition. Nature 426(6964), 323-326.

Bernet, M., 2009. A field-based estimate of the zircon fission-track closure temperature. Chemical Geology 259(3-4), 181-189.

Bo, S., Siegert, M. J., Mudd, S. M., Sugden, D., Fujita, S., Xiangbin, C., et al., 2009. The Gamburtsev mountains and the origin and early evolution of the Antarctic Ice Sheet. Nature 459(7247), 690.

Campion, A., Maloof, A., Schoene, B., Oleynik, S., Sanz-López, J., Blanco-Ferrera, S., Pedro Fernández, L., 2018. Constraining the Timing and Amplitude of Early Serpukhovian Glacioeustasy with a Continuous Carbonate record in Northern Spain. Geochemistry, Geophysics, Geosystems 19 (8), doi: 10.1029/2017GC007369. 
Caputo, M. V., de Melo, J. H. G., Streel, M., Isbell, J. L., 2008. Late Devonian and early Carboniferous glacial records of South America. Geological Society of America Special Papers 441, 161-173.

Chen, J., Montañez, I. P., Qi, Y., Shen, S., Wang, X., 2018. Strontium and carbon isotopic evidence for decoupling of $\mathrm{pCO}_{2}$ from continental weathering at the apex of the late Paleozoic glaciation. Geology 46(5), 395-398.

Cox, S. E., Thomson, S. N., Reiners, P. W., Hemming, S. R., van de Flierdt, T., 2010. Extremely low long-term erosion rates around the Gamburtsev Mountains in interior East Antarctica. Geophys. Res. Lett. 37, L22307.

Cuffy, K.M., Paterson, W.S.B., 2010. The Physics of Glaciers (4th ed.). Academic Press.

Davydov, V. I., Biakov, A. S., Isbell, J. L., Crowley, J. L., Schmitz, M. D., Vedernikov, I. L., 2016. Middle Permian U-Pb zircon ages of the "glacial" deposits of the Atkan Formation, Ayan-Yuryakh anticlinorium, Magadan province, NE Russia: their significance for global climatic interpretations. Gondwana Research 38, 74-85.

Domeier, M., Van Der Voo, R., Tohver, E., Tomezzoli, R.N., Vizan, H., Kirshner, J., 2011. New Late Permian paleomagnetic data from Argentina: refinement of the apparent polar wander path of Gondwana. Geochemistry, Geophysics, Geosystems 12, 1-21.

Duclaux, G., Rolland, Y., Ruffet, G., Ménot, R. P., Guillot, S., Peucat, J. J., Fanning, M., Rey, P., Pêcher, A., 2008. Superimposed Neoarchaen and Paleoproterozoic tectonics in the Terre Adélie Craton (East Antarctica): evidence from Th-U-Pb ages on monazite and ${ }^{40} \mathrm{Ar} /{ }^{39} \mathrm{Ar}$ ages. Precambrian Res. 167, 316-338.

Dow, J. A. S., Neall, V. E., 1974. Geology of the lower Rennick Glacier, northern Victoria Land, Antarctica. New Zealand Journal of Geology and Geophysics 17(3), 659-714. 
Ehlers, T. A., Chaudhri, T., Kumar, S., Fuller, C. W., Willett, S. D., Ketcham, R. A., et al., 2005. Computational tools for low-temperature thermochronometer interpretation. Reviews in Mineralogy and Geochemistry 58(1), 589-622.

Enkelmann, E., Zeitler, P. K., Garver, J. I., Pavlis, T. L., Hooks, B. P., 2010. The thermochronological record of tectonic and surface process interaction at the YakutatNorth American collision zone in southeast Alaska. American Journal of Science 310(4), 231-260.

Farley, K. A., Wolf, R. A., Silver, L. T., 1996. The effects of long alpha-stopping distances on (U-Th)/He ages. Geochimica et cosmochimica acta 60, 4223-4229.

Ferraccioli, F., Finn, C. A., Jordan, T. A., Bell, R. E., Anderson, L. M., Damaske, D., 2011. East Antarctic rifting triggers uplift of the Gamburtsev Mountains. Nature 479(7373), 388.

Fillon, C., Gautheron, C., van der Beek, P.A., 2013. Oligocene-Miocene burial and exhumation of the Southern Pyrenean foreland quantified by low-temperature thermochronology. Journal of the Geological Society 170, 67-77.

Fitzgerald, P.G., 1994. Thermochronologic constraints on post-Paleozoic tectonic evolution of the central Transantarctic Mountains, Antarctic. Tectonics 13(4), 818-836.

Flowers, R. M., Ketcham, R. A., Shuster, D. L., Farley, K. A., 2009. Apatite (U-Th)/He thermochronometry using a radiation damage accumulation and annealing model. Geochimica et Cosmochimica acta 73(8), 2347-2365.

Foster, D. A., Gleadow, A. J., 1992. Reactivated tectonic boundaries and implications for the reconstruction of southeastern Australia and northern Victoria Land, Antarctica. Geology 20(3), 267-270.

Frakes, L.A., Matthews, J.L., Crowell, J.C., 1971. Late Paleozoic glaciation: Part III. Antarctica: Geological Society of America Bulletin 82, 1581-1604. 
Gallagher, K., Brown, R., Johnson, C., 1998. Fission track analysis and its applications to geological problems. Annu. Rev. Earth Planet. Sci. 26, 519-572.

Gautheron, C., Tassan-Got, L., Barbarand, J., Pagel, M., 2009. Effect of alpha-damage annealing on apatite (U-Th)/He thermochronology. Chemical Geology 266, 157-170.

Gautheron, C., Tassan-Got, L., Ketcham, R.A. and Dobson, K.J. 2012. Accounting for long alpha-particle stopping distances in (U-Th-Sm)/He geochronology: 3D modeling of diffusion, zoning, implantation, and abrasion. Geochimica et Cosmochimica Acta 96, 4456.

Goddéris, Y., Donnadieu, Y., Carretier, S., Aretz, M., Dera, G., Macouin, M., Regard, V., 2017. Onset and ending of the late Palaeozoic ice age triggered by tectonically paced rock weathering. Nature Geoscience 10(5), 382.

Hallet, B., Hunter, L., Bogen, J., 1996. Rates of erosion and sediment evacuation by glaciers: A review of field data and their implications. Global and Planetary Change, 12(1-4), 213235.

Hand, S.J., 1993. Palaeogeography of Tasmania's Permo-Carboniferous glacigenic sediments. In: R.H. Findlay et al. (Editors), Gondwana Eight, Assembly, Evolution and Dispersal. Balkema, Rotterdam, pp. 459-469.

Harrowfield, M., Holdgate, G. R., Wilson, C. J., McLoughlin, S., 2005. Tectonic significance of the Lambert Graben, East Antarctica: reconstructing the Gondwanan rift. Geology 33(3), 197-200.

Hay, W. W., Shaw, C. A., Wold, C. N., 1989. Mass-balanced paleogeographic reconstructions. Geologische Rundschau 78(1), 207-242.

Hourigan, J.K., Reiners, P.W. Brandon, M.T., 2005. U-Th zonation-dependent alpha-ejection in (U-Th)/He chronometry. Geochemica et Cosmochimica Acta 69, 3349-3365. 
Isaacson, P. E., Diaz-Martinez, E., Grader, G. W., Kalvoda, J., Babek, O., Devuyst, F. X., 2008. Late Devonian-earliest Mississippian glaciation in Gondwanaland and its biogeographic consequences. Palaeogeography, Palaeoclimatology, Palaeoecology 268(3-4), 126-142.

Lakin, J. A., Marshall, J. E. A., Troth, I., Harding, I. C., 2016. Greenhouse to icehouse: a biostratigraphic review of latest Devonian-Mississippian glaciations and their global effects. Geological Society, London, Special Publications 423, SP423-12.

Isbell, J. L., 2010. Environmental and paleogeographic implications of glaciotectonic deformation of glaciomarine deposits within Permian strata of the Metschel Tillite, southern Victoria Land, Antarctica. Late Paleozoic Glacial Events and Postglacial Transgression in Gondwana: Geological Society of America Special Paper 468, 81-100.

Isbell, J.L., Koch, Z.J., Szablewski, G.M., Lenaker, P.A., 2008. Permian glacigenic deposits in the Transantarctic Mountains, Antarctica, in Fielding, C.R., Frank, T.D., and Isbell, J.L., (eds.), Resolving the Late Paleozoic Ice Age in Time and Space. Geological Society of America Special Paper 441, 59-70.

Isbell, J. L., Henry, L. C., Gulbranson, E. L., Limarino, C. O., Fraiser, M. L., Koch, Z. J., et al., 2012. Glacial paradoxes during the late Paleozoic ice age: evaluating the equilibrium line altitude as a control on glaciation. Gondwana Research 22(1), 1-19.

Isbell, J. L., Biakov, A. S., Vedernikov, I. L., Davydov, V. I., Gulbranson, E. L., Fedorchuk, N. D., 2016. Permian diamictites in northeastern Asia: Their significance concerning the bipolarity of the late Paleozoic ice age. Earth-Science Reviews 154, 279-300.

Ketcham, R. A., Carter, A., Donelick, R. A., Barbarand, J., Hurford, A. J., 2007. Improved modeling of fission-track annealing in apatite. American Mineralogist 92(5-6), 799-810.

Ketcham, R.A., Gautheron, C., Tassan-Got, L., 2011. Accounting for long alpha-particle stopping distances in (U-Th-Sm)/He geochronology: refinement of the baseline case. Geochimica et Cosmochimica Acta 75, 7779-7791. 
Koppes, M., Hallet, B., Rignot, E., Mouginot, J., Wellner, J. S., Boldt, K., 2015. Observed latitudinal variations in erosion as a function of glacier dynamics. Nature 526(7571), 100.

Koch, Z. J., Isbell, J. L., 2013. Processes and products of grounding-line fans from the Permian Pagoda Formation, Antarctica: insight into glacigenic conditions in polar Gondwana. Gondwana Research 24(1), 161-172.

Lamarque, G., Barruol, G., Fontaine, F., Bascou, J., Ménot, R.P., 2015. Deep structure of the lithosphere beneath the Terre Adélie Craton - insights from receiver functions and anisotropy measurements. Geophys. J. Int. 200, 809-823.

Lamarque, G., Bascou, J., Ménot, R. P., Paquette, J. L., Couzinié, S., Rolland, Y., Cottin, J. Y., 2018. Ediacaran to lower Cambrian basement in eastern George V Land (Antarctica): Evidence from UPb dating of gneiss xenoliths and implications for the South AustraliaEast Antarctica connection. Lithos 318, 219-229.

Lisker, F., Olesch, M., 2003. Long-Term Landscape Evolution of George V Land as Indicated by Fission Track Data. Terra Antartica 10, 249-256.

Lisker, F., Brown, R., Fabel, D., 2003. Denudational and thermal history along a transect across the Lambert Graben, northern Prince Charles Mountains, Antarctica, derived from apatite fission track thermochronology. Tectonics 22,1055.

Ménot, R. P., Pecher, A., Rolland, Y., Peucat, J. J., Pelletier, A., Duclaux, G., Guillot, S., 2005. Structural Setting of the Neoarchean Terrains in the Commonwealth Bay Area (143$\left.145^{\circ} \mathrm{E}\right)$, Terre Adélie Craton, East Antarctica. Gondwana Research 8(1), 1-9.

Ménot, R.P., Duclaux, G., Peucat, J.J., Rolland, Y., Guillot, S., Fanning, C.M., Bascou, J., Gapais, D. and Pêcher, A., 2007. Geology of the Terre Adélie Craton (135 - 146 E), 10th ISAES. USGS, Santa Barbara.

Montañez, I. P., Poulsen, C. J., 2013. The Late Paleozoic ice age: an evolving paradigm. Annu. Rev. Earth Planet. Sci. 41, 629-656. 
Montañez, I. P., McElwain, J. C., Poulsen, C. J., White, J. D., DiMichele, W. A., Wilson, J. P., Hren, M. T., 2016. Climate, $\mathrm{pCO}_{2}$ and terrestrial carbon cycle linkages during late Paleozoic glacial-interglacial cycles. Nat. Geosci. 9, 824-828.

Ohmura, A., Kasser, P., Funk, M., 1992. Climate at the equilibrium line of glaciers. Journal of Glaciology 38, 397-411.

Reiners, P. W., Brandon, M. T., 2006. Using thermochronology to understand orogenic erosion. Annu. Rev. Earth Planet. Sci. 34, 419-466.

Rygel, M. C., Fielding, C. R., Frank, T. D., Birgenheier, L. P. 2008. The magnitude of Late Paleozoic glacioeustatic fluctuations: a synthesis. J. Sed. Res. 78(8), 500-511.

Shuster, D. L., Flowers, R. M., Farley, K. A., 2006. The influence of natural radiation damage on helium diffusion kinetics in apatite. Earth and Planetary Science Letters 249(3-4), $148-161$.

Thomson, S. N., Brandon, M. T., Tomkin, J. H., Reiners, P. W., Vásquez, C., Wilson, N. J., 2010. Glaciation as a destructive and constructive control on mountain building. Nature $467,313-317$.

Thomson, S. N., Reiners, P. W., Hemming, S. R., Gehrels, G. E., 2013. The contribution of glacial erosion to shaping the hidden landscape of East Antarctica. Nature Geoscience 6(3), 203-207.

Torsvik, T.H., Müller, R.D., Van der Voo, R., Steinberger, B., Gaina, C., 2008. Global plate motion frames: toward a unified model. Review of Geophysics 46, 1-44.

Veevers, J.J., 2006. Updated Gondwana (Permian-Cretaceous) earth history of Australia. Gondwana Research 9, 231-260.

Wolf, R. A., Farley, K. A., Kass, D. M., 1998. Modeling of the temperature sensitivity of the apatite (U-Th)/He thermochronometer. Chemical Geology 148, 105-114. 